\title{
Binding and arresting: Surface and pattern in a contemporary traditional Pacific building
}

Fig. 1 South-west approach to the Fale Pasifika, University of Auckland [Photo: Author, 2017]

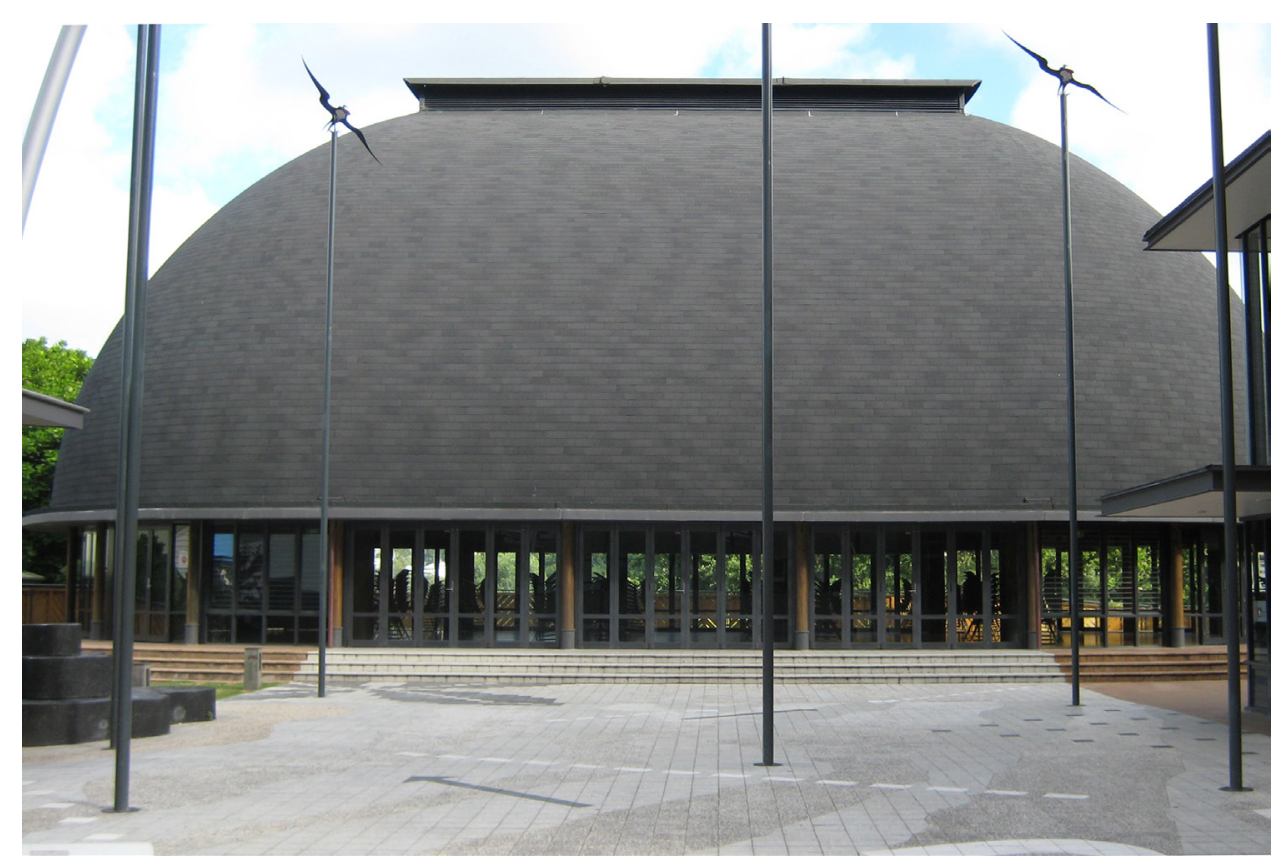

\section{Fale Pasifika, University of Auckland}

Approaching the Fale Pasifika through a gateway with commissioned works by Tomui Kaloni and Jim Vivieaere, and passing by the Pacific Studies complex with prints of John Pule's drawings on various windows, it is the fale's great roof that impresses when crossing the malae (a potentially sacred, open space), designed by Tania Short whose paved patterns signal the ocean, asserting it as a ground of identity (Fig. 1). Watching all approach is a pou (pole) by Fatu Feu'u (Refiti, 2015: 24).

One can enter the fale (house) both from the wide front, in the Samoan way, or from its narrow side in the Tongan manner. On a summer's day, the interior is dark against the glare of the lower strip of light until the eyes adjust and the roof volume becomes discernible (Fig. 2). Structurally this upper space echoes the poles, beams and crossbeams of a Samoan fale afolau and fale Tonga (24) yet it 
has no 'au'au (ridgepole), nor do its poles penetrate the earth-they rest in metal sleeves bolted onto the roof of a carpark below.

While community representatives participated in the design and construction through a planning committee, no tufuga faufale (master builder) was involved. Instead, architect Ivan Mercep consulted Te Rangi Hīroa Buck's Samoan Material Culture (1949) to determine the Fale Pasifika's roof shape and proportions. Nevertheless, the building projects a "particular iconic presence" (Refiti, 2015: 5). The structural framework and the lalava (lashings) are characteristic primarily of Samoa or Tonga, but some patterns are shared with other Polynesian, Micronesian and Melanesian cultures. A pan-Pacific identity is in the process of becoming here. For the non-initiated, the lalava contribute to a complexely patterned enclosure that makes the fale a desirable venue at the University of Auckland (pers. comm. Melani Anae, 10.5.2017).

The institution regards the Fale Pasifika as one of its "more iconic buildings" and an important "touch-point between the University and Pacific communities" (University of Auckland, n.d.). It provides common ground for staff and students and brings "Pacific issues and identity into the heart of the University's affairs" (University of Auckland, n.d.).

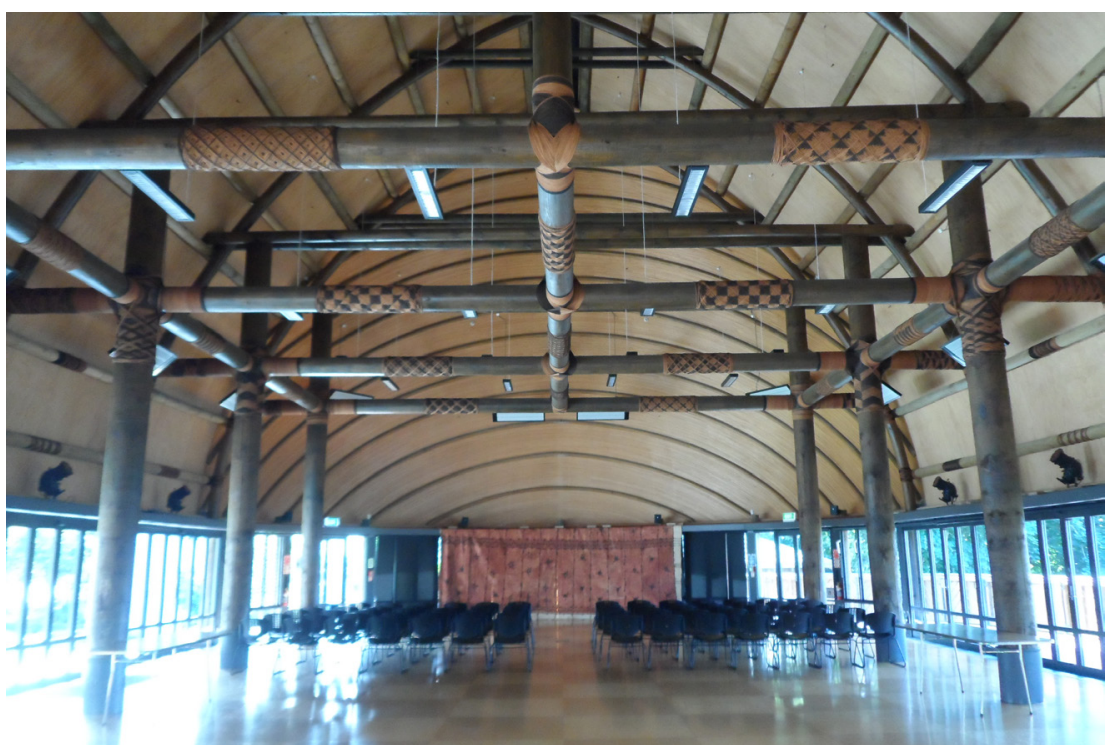

The rich layering of structural, contextual, performative, material and symbolic features contributing to the Fale Pasifika's iconicity is striking: its setting in the open space; the roof shape and the transparent base over the stepped platform; the materials and semiotics of its internal structure; the processes connecting it with Pacific communities within and outside the university-they all make up an integral whole from which it is neither fully possible nor desirable to extract any particular facet or feature. However, in this paper, I will investigate the particular role surfaces and patterns play in the production of affective and effective relationships indicative of a Pacific sense of place and identity, and how they tangibly represent, not only for Pacific users, "something 'Pacific"' (Mallon, 2010: 27). In the process, I will argue for a different understanding of iconicity (Bartmański \& Alexander, 2012: 11), which offers new and relevant insights into processes of identification and community building through material things. 


\section{Surface and pattern}

Traditional surfaces and patterns are important aspects of the fale's iconic presence. However, traditional is, of course, an English word and may or may not describe a Pacific phenomenon adequately. Such terms come with their "own histories and own ways of being thought about", which owe much of their thrust to a "colonial trade with wildness that ensures civilization its savagery" (Taussig, 1993: xix). To use such notions (even to pair them with Pacific correspondences in a spirit of conceptual openness without claims of strong adequacy, see Ricœur, 2006:10), inescapably activates these histories and profoundly influences practices of representation (Taussig, 1993: xix).

Albert Wendt, for example, when asked in a 2017 interview about his thoughts on fa'atupua and tupua as equivalents to icon or iconic, noted that the missionaries probably translated God as atua, rather than tupua, because the latter was more commonly used and more decidedly plural (pers. comm. 19.4.2017) - a notion incompatible with Christian theology. Fa'atupua seemed particularly problematic to Wendt, for its associations with idol or fetish by the missionaries served to distinguish their God from the heathens' idols. This distinction still impacts Pacific and Western concepts, because "the manner of seeing decides what can be seen", and the mode of apprehension decides "everything between the idol and the icon" (Marion \& Tracy, 2012: 9).

Under the continued influence of a tradition in which tradition is a dirty word, Wendt took care to call Samoan architecture classical, rather than traditional. Modernist disdain for tradition is now itself recognisable as tradition, and the related derision of ornamentation, similarly, lacks reliable theoretical foundation (see Gordon, 1992). Both were nevertheless used (in anthropology and art theory) to disqualify the art of traditional, 'primitive' societies. Calling someone's pattern ornament can still cause offense and, in the late 1990s, Māori design educators I interviewed vehemently rejected this term when applied to things Māori.

By contrast, Futa Helu (founder of 'Atenesi University, Tonga) regarded tradition as the manifestation of a wish for "some degree of permanence" in an ever-changing life, in which everything ultimately disappears (2012 @ 1:02:1052). Hannah Arendt similarly observed (earlier and at the antipodes) that the wish for permanence beyond an individual's life span motivates the making of things, particularly art $(1958 / 1998: 152,173)$. In the fale construction, this includes the production of refined surfaces (see fig. 26 in Refiti, 2015: 163), where time and tradition are indispensable for the accretion of meaning and value in pattern.

Further, people are sustained 'in place' by specific "historical connections and disconnections", which provide them with agency (Clifford, 2000: 96). Situated use of language, objects and practices creates specific meanings that are intimately bound up with local life (Wittgenstein, 1958). With the intensification of modernisation in Europe, mobility and changing social spheres in Europe rendered tradition problematic (see Clifford, 2000: 98). At the beginning of the twentieth century, with collective systems of meaning weakened, ornament itself lost much of its social import-a condition often felt as irreversible (Engels-Schwarzpaul, 2001: 102). An echo of such loss is also palpable in Malama Meleisea's comment a hundred years later: "The loss of oral traditions, artefacts, records of past events, art and music can only result in the spiritual impoverishment of a nation" (1981: 123). 
Meleisea in Samoa and Helu (1993) in Tonga have both clearly identified a link between increasingly complex social systems and the loss of certain elements of tradition. Yet, is this loss the same as the earlier one in Europe? While Meleisea seems to share a modernists view that "culture cannot be preserved by trying to make people re-create and imitate past forms" (1981: 123), he continues on in a different direction: living cultures grow and develop creatively from traditional heritage, and heritage continues to give meaning to people's life, as traditions (123). Not surprisingly, perhaps, Meleisea reverses the temporality ascribed to tradition in the West; rather than the past being put behind, from a Pacific perspective, one walks backward into the future with the past firmly in sight (Hau'ofa, 2008: 66).

Gathering up and performing traditions-“never simply backward-looking”, but as part of "belonging to some discrete social time and place in an interconnected world" (Clifford, 2000: 97)-helps link pasts and futures. Forms of indigenous traditionalism engage Pacific material culture more creatively than the nostalgia engendered by Western beliefs in progress. They are kin to the European Renaissance, which "returned to a classical past to innovate a dynamic future" (100). Aby Warburg showed in the early twentieth century that the Florentine Renaissance was not a rebirth following extinction, as the word would suggest, but the selective activation of a Nachleben (afterlife or survival) of images and motifs (Didi-Huberman, Rehberg \& Belay, 2003: 273). Nachleben involves "forgetting, the transformation of sense, involuntary memory, and unexpected rediscovery" (275), forming a web of memory, rather than an account of a particular history, that includes pauses, crises, leaps and periodic versions. The past constantly marks the present, and the process can either run regressively towards an imitation of the past or progressively and creatively to rework a tradition (Rampley, 2001b: 102). Less like an unbroken river, which accumulates from upstream to downstream, this dialectic tradition unfolds "between the river's flow and its whirling eddies" (Didi-Huberman et al., 2003: 276). A form can survive its own death: disappear at some historical moment and reappear laterthus surviving in collective memory (Didi-Huberman, 2002: 68).

Displaced yet persistent, in a new mode of signification, surviving images testify to their past as ghostly manifestations (65). Seen as survivals, the Fale Pasifika's iconic elements (shape, material surfaces, patterns or ornaments) are "form[s] of temporal turmoil" (Papapetros, 2003: 169), a play or knot of heterogeneous temporalities, themselves vested in collective memory and recoverable to varying degrees and in different ways (see Engels-Schwarzpaul, 2001: 11-12; Rampley, 2000: 90-97). As artefacts, these iconic elements embody, as Alfred Gell has noted, "residues of complex intentionalities" (1996: 37), particularly in diasporic situations, where iconic objects and patterns acquire additional layers of meaning. When customary life has to be abandoned, traditions can be crucial, "because those who don't have a past won’t have a future” (Syrian refugee in Sinjab, 2016 @ 12:25mins). Edward B. Tyler (whose notion of survival Warburg most likely appropriated) noted that "multiple pasts" are interwoven in the "vertiginous play of time in the present [...] 'surface' of a given culture" (Didi-Huberman, 2002: 63). As parts of the current surface of a culture, objects can help recover traditions, intentions, memories and emotions-in short, to build a future.

In English, surface, as a noun, designates the visible outside of something that encloses its invisible elements-hence the phrase "on the face of it". The verb 
surface, by contrast, indicates a depth relationship, implying that something invisible becomes visible. The verbal form, closer to Tyler's use of surface, relates to a Pacific conception that tattooing and other art forms activate "a (sur)facing that allows the body [and certain objects] to look towards the world" (Refiti, 2007). But surface must first be produced, refined, made even to make space for outward, textured expressions. In Samoa, the surfaces of measina (luminous-white and treasured objects) are smoothed, whitened and bleached, then elevated and revealed (Refiti, 2015: $15 \& 128$ ). As production, this is a "marking off of value" (Clifford, 2000: 99) requiring an investment of labour, which has the effect of removing things from the ordinary and making them stand out against the flow of nature and change. The smoothing of surfaces mirrors an adornment by ornaments-the first being the condition of possibility for the latter. In Samoan culture, measina asserts a surface condition in which "the present is woven with multiple pasts" (Didi-Huberman, 2002: 63).

Without surface, pattern cannot emerge. Refined surface without pattern remains pure possibility. Yet, when patterns intertwine sensuous surface with depth-meaning, they can be understood simultaneously (Alexander, Bartmański \& Giesen, 2012: 32). Surface, then, is "the necessary interface of the material feeling of meaning", which remains "connected to other symbols and whole constellations of meaning” (Bartmański, 2015:17). Iconic power, thus, crucially concerns materiality-skin and blood in the case of tattoo, wood and sennit in the case of the fale-hence icons are bundles of material/aesthetic surface and immaterial/spiritual, moral or intellectual depth. In the "performative fusion of surface and depth" (17), iconic aspects of patterns in the Fale Pasifika are activated in specific experiential clusters (24). Surface, here, is the indispensable interface across which meaning, labour and value converge with "often visceral collective feelings" (27), and on which pattern fuses material, narrative and social significance in iconic performativity. Surface patterns are not merely traditional but living iconic survivals, in which collective feelings can consolidate and "become conscious of themselves" (Durkheim \& Fields, 1995: 421).

\section{The Iconic: Binding and arresting}

Patterned surfaces, then, do not simply enclose objects but reveal them-in energetic mediations of past and present, individual and collective meanings, aesthetic affect, material experience and cultural representation (Bartmański, 2015: 28). In the Fale Pasifika, they mediate obvious meanings understood by most people, yet they also hint at something less obvious. Iconic power, according to Charles S. Peirce, relies on the excitement of ideas that are naturally allied with the associations an object or building would itself excite (1998: 13). An icon represents its object mainly by its sensory similarity (273), which is commonly taken as visual. However, icons can also be diagrams that do not "resemble their objects [...] at all in looks" (13)-instead, their likeness consists in "the relations of their parts" (13). Samoan fale tele (great house) routinely shelter and perform relationships, and their diagrammatic layout allocates specific pou (posts) to particular fanua (families). The pou re-present descent lines and enact connections between them. The combination of visual and diagrammatic iconicity, in a "felicitous performative arrangement of visually arresting phenomenon and socially potent meanings and their references" (Bartmański, 2015: 3), involves material objectifications of thoughts and feelings. In this way, the Fale Pasifika is able to 
activate aspects "invisible yet still alive in local hearts and memory", aspects that are "still there" (Tengan \& Roy, 2014: 315, 322) in the present surface of diasporic culture. Its formal and material qualities are much more than remnants of classic Pacific architecture.

For Gell, the decoration of objects is a particular social "technology of enchantment" (1998: 74) adding to an object's psychological functionality. Gell rejects distinctions between the beautiful and the useful arising out of a Western cultural heritage of Judeo-Christian and Islamic histories of images (1998: 4-6, 96). His theory of pattern, which addresses the physical agency inherent in non-representational decorative forms, speaks to some elements of the Fale Pasifika. Patterns allow the physical body of an object to become "a "living thing"' through "visual properties of repetitiveness and symmetry" (76-77). In a similar vein, Warburg argued that 'symbolic images' are neither ornamental nor ultimately explicable by iconographic methods-rather, they play an "originary, constitutive role for thinking, interpretation, and [...] being”, like metaphor constantly renewing intuition (Johnson, 2012: 18; Brody, 1987).

This constitutive role of symbolic images for thinking may explain both the Fale Pasifika's iconic appearance and the development of a concept central to Pacific identity formation in the diaspora, the vā. This "Unity-that-is-all" (Wendt, 1996) is the space in which all relationships unfold. As one of the alternative concepts indigenous populations in the Pacific region use to confront prevailing Western geographies of power/knowledge, the $v \bar{a}$ manifests desires for "a common space of belonging, based on mutual respect" (Refiti, 2015: 14) in diverse but related communities. The Samoan maxim, "ia teu le $v \bar{a}$ " refers to the orientation of people in that space, the proper order in which "to face the ancestors" (Refiti, 2009: 16). Teu, producing, "embellishing and adorning the space of the ancestor", is also the tufuga's task of opening and orienting space in the fale tele by dressing the timber, measina ("the bleaching and whitening of the materiality of the world", 15). Constantly reworked interpretations of such central concepts, which preserve both differences and identity, increase the Fale Pasifika's iconic power to serve, shelter, extend and adorn the $v \bar{a}$. Wendt, a key person during the planning phases, recalls that the fale owes its classical forms to the influence of Pacific community members on the committee, so that tufuga lalava Filipe Tohi created classical

Fig. 3 Lalava patterns at the Fale Pasifika [Photo: author, 2917] Tongan lalava which, though no longer serving structural purposes, lashed-up cultural meanings with group and personal identities.
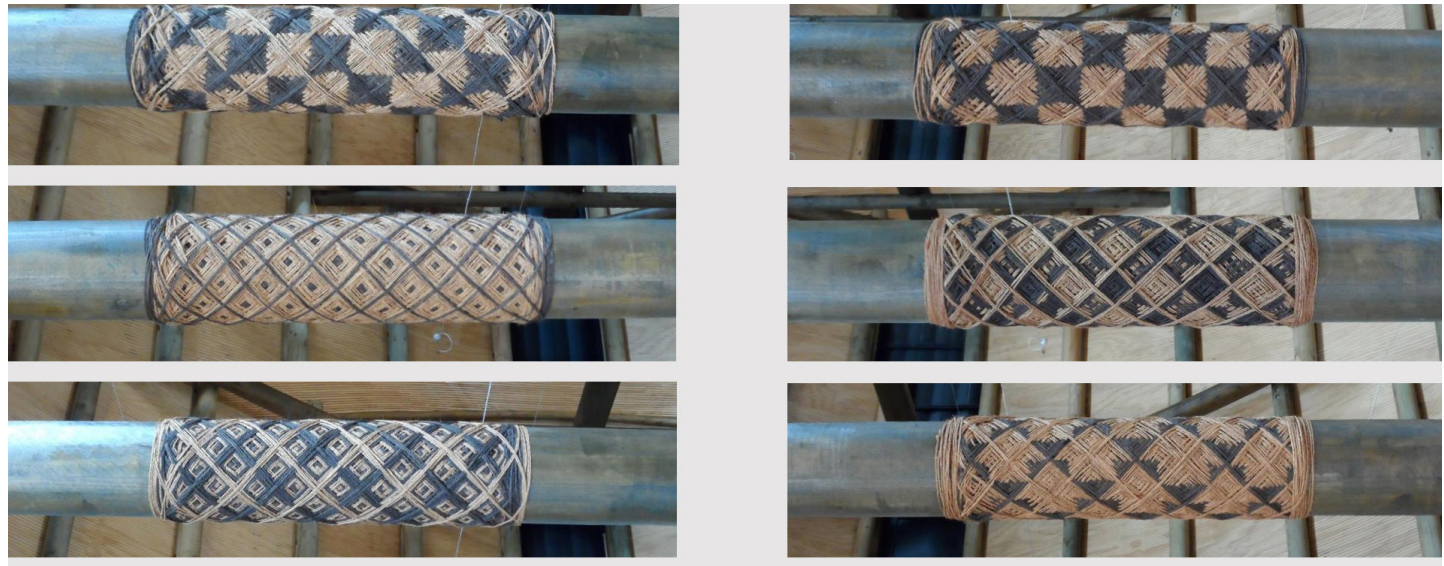
Several forms of signification operate simultaneously: first, the fale diagrammatically represents cosmic relationships (Refiti, 2015: 206f, 219f, 223f) and relationships of families with their lands. In the diaspora, such iconicity acquired a stronger look-alike aspect: the building looks like classical buildings in the homelands, which served as communal meeting spaces. At the same time, only some initiated community members or visitors would understand the lalava patterns' highly conventional form of diagrammatical representation. For those who do not understand the specific cognitive or emotional relationships, the patterns still act on perception, thanks to their specific relationships of parts exploiting "particularly (visually) salient part-to-part relationships produced by the repetition and symmetrical arrangement of motifs" (Gell, 1998: 76).

The lalava's application to the beams' surfaces "multiplies the number of [...] parts and the density of their internal relationships" (76). Establishing an agentive disposition of internal reference that animates the patterns, it brings them to life in a non-representational way, and draws our perception into the relationships in and between the motifs. These relationships, binding forces between arresting figures, ensnaring ground and viewers, are founded on the experience of a "mimetic passing over into the object" (Rampley, 1997: 45). We are trapped or hooked (Gell, 1998: 80), and our relationship to the artefacts bearing the pattern changes: 'unfinished business' (caused by the cognitive gap in grasping the pattern's complexity) becomes a binding force that is never resolved but always in a "renewed, residual imbalance" (81). Patterns slow down perception; the object "is never fully possessed" but "always in the process of becoming possessed", setting up biographical relations between artefact and recipients (81), as well as between recipients.

Iconic consciousness always involves an understanding "by feeling, by contact, by the evidence of the senses rather than the mind" (Alexander, 2015: 4). Materiality, however, also enables abstract thoughts: in order "to express our own ideas even to ourselves, we need to attach those ideas to material things that symbolize them" (Durkheim \& Fields, 1995: 229). Collective feelings "become conscious of themselves only by settling upon external objects" and by taking on some of their traits, their physical nature, so that they come to mingle "with the life of the physical world" (421-22). Cultural content, therefore, is principally material, entangled, and embedded in specific practices (Bartmański, 2015: 26). How icons "participate in the invention or the re-invention of the real" (Pier, 1997: 213), and how or whether they can provide a model for its elaboration, depends on their relationship with meaning and practice more widely, and on their participation in a "dialectic of negation and preservation" (Rampley, 2001a: 307). Thus, while some of the fale's visual aspects effectively anchor meaning and memories, visual likenesses can also float as generalized signifiers, meaning different things in different contexts to different people. Moreover, there is always a productive, enigmatic rest that interpretation or translation cannot exhaust. This is both a failure of signification and the fertile groundswell of the iconic mode, whose elaboration invariably involves some form of appropriation and/or mimesis.

Fau, in tufuga faufale, means "bind together, build" (Pratt, 1893), and a tufuga faufale is an expert in binding a house together. Filipe Tohi did just that, even though the lalava no longer structurally bind the posts together. In the Fale Pasifika's technical production, an advisory group and a team of engineers, architects, quantity surveyors and project managers replaced the tufuga faufale. Tohi, 
Fig. 4 Lalava covering post/beam connection [Photo: author, 2017]

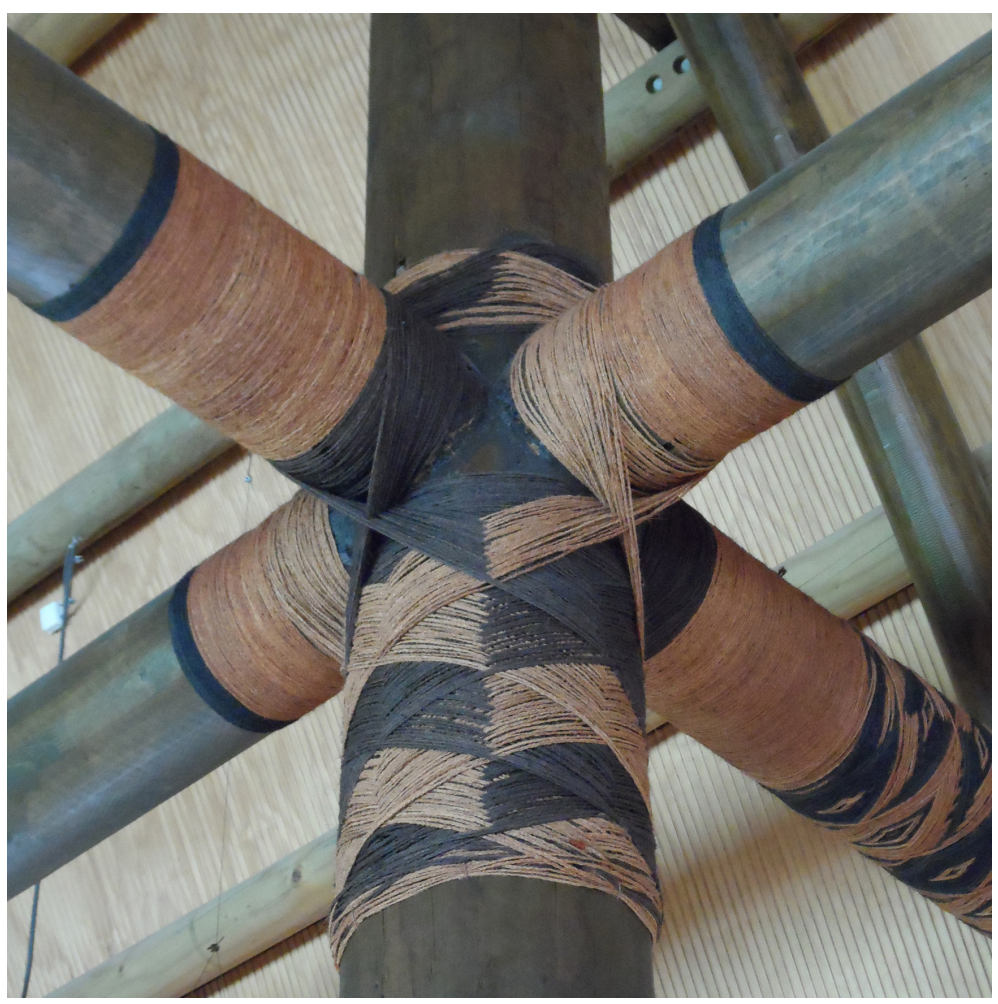

however, self-consciously lashed-up cultural meanings with group and personal identities. That the fale was planned and built with the ongoing support of an advisory committee representing different Pacific groups helped build a community. Its members assemble in the fale and materially and experientially mediate, or trans-late, traditional processes, structures and materials to this new environment. The building increasingly becomes a catalyst for a NZ-born, Pasifika identity and produces effective and affective ties between the communities, students and academics it serves. Their resulting sense of belonging is simultaneously indebted to an original setting and committed to a new community (Refiti, 2015: 5). Displacement necessitates new interpretations, alignments and configurations, as people seize hold of material objects from their homeland to keep them going and manage times of crisis. The success of this project, its iconicity being a contributing factor, amounts to symbolising and effecting "relations of mana" (Tomlinson \& Tengan, 2016: 17) for Pacific communities in Auckland, as well as channelling affective force through the creation of lasting relationships.

Tomlinson and Tengan note that forms based on "repetition, balance and complementarity" not only operate aesthetically but can transfer and channel mana (2016: 17). For communities able to participate, the lalava patterns establish and maintain linkages between the living, the dead and the cosmos. Repetition "symbolise[s] and effect[s] relations of mana" (2016a: 17), not only in traditional houses in their original context but also in contemporary ones in the diaspora. The continued survival, the Nachleben, of roof shape, proportions, structural framework and lalava testifies, in their very displacement, to the permanence and persistence of mana in Pacific diasporic culture. These forms are instrumental in making visitors "recognize and acknowledge the sovereignty and mana of whose space [they] are in at all times" (Tengan \& Roy, 2014: 327). In this way the iconic, including the iconic surface, captures and binds new communities. 


\section{Transformative appropriation: Harnessing iconic power}

Objects and buildings have iconic power when they function both at an immediate, sensory level and at the level of collective consciousness. As a catalyst for community building, they are both theoretically and practically important. Yet, the iconic has long been neglected and misunderstood in the Western intellectual tradition, which conceived of icons as "superficial, deceptive, and ultimately even as socially dangerous", despite the fact that non-experts have found them inspiring (Bartmański \& Alexander, 2012: 11). Like ornament, icons were attributed to the non-educated or to non-Western cultures (Engels-Schwarzpaul, 2001: 3 , fn. 10). Ironically, with its pejorative context removed, the association may describe modes of identification and solidarity that modern, rationalist analyses misrecognised or discarded prematurely, for ideological reasons.

Re-appropriating the iconic promises not only a different understanding of the processes it supports (e.g., specific surface/pattern phenomena) but also a starting point from which to engage them in practice. If the Fale Pasifika's overall shape and details still have the power to bind participating communities (although important aspects are neither traditional nor classical), this is due also to Tohi's transformative appropriations. Tohi followed tohunga whakairo (Māori, master carver) Paki Harrison's example, who carved Tane-nui-a-Rangi, the Māori wharenui (meetinghouse) on the University of Auckland campus, and chose traditional patterns shared by different communities from in-and-outside the Pacific. The wharenui's pou relate not only to different Māori groups, but also to Pacific homelands and European places of departure and Tohi, like Harrison, carefully provided multiple entry points for diverse audiences (pers. comm. 29.3.17). He was clearly aware of iconic power as valuable strategic resource and ordering principle and used iconic patterns to galvanize narratives and juxtapose perspectives. Thus, unlike an "apparatus that gathers and controls" hierarchical village relationships (Refiti, 2015: 229), the fale relates different groups in the diaspora horizontally. As diagram, and through visual similarity, it continually re-presents and shapes a Pasifika identity.

An important and interesting question in this context concerns the relationship of the iconic with mana. Tomlinson and Tengan describe, in their introduction to New Mana (2016b), processes of mana's "transformation in appropriation" (14) in politics, religion, art and commerce. They note that, in the iconic 2010 exhibition of three temple images of Kū in Honululu, "modernday Hawaiians" worked, in aesthetic terms, "to 'read' the designs that were unfamiliar to many", realising that "patterns and motifs were not just decorative but spiritually potent and practically useful" (2016: 22). They refer to Wendt's definition of mana as an "artistic and imaginative energy" drawn from the totality of the artist's environment, reconstituted and then transmitted back into the community-a power to explore "unfettered by accepted conventions" (xvi). This take on mana is worlds apart from anthropology's supernatural power (Codrington) or floating signifier (LéviStrauss; at first sight, it also seems contrary to customary Pacific use). Mana now empowers contemporary Pacific artists and activists, who re-appropriate and transform an anthropological technical term to their own ends. Similarly, there might be value in taking hold of the concept iconic to return to it an imaginative, generative power able to energise communities. According to Tengan, the creative, aesthetic work of understanding "the mana of Kù aesthetically" can be "an opportunity for reconnection and recreation of culture and mana" (22). 
If mana is, in the widest sense, a spiritual and creative energy or power that circulates between individual, community and cosmos, and if it can contribute to the (re)building of culture and community (Tengan, 2014: 217), then iconic practices may, in certain contexts, support the circulation of mana. MacCannell argues that icons "cannot be suspended in a single consciousness but can only exist in a group setting" (1992: 237). An iconic image is exalted by the co-participating members (240) and it is through this exaltation, the participation of "real people in real situations" in the "living present" and a "particular unification of audience and performance" (242), that the icon derives a power that can then be circulated back into the community.

An iconic building that is an integral part of diasporic community life can thus be charged with energy and iconic power and, in turn, galvanize the community. While the appropriation of classical Pacific architecture by the "cultural revival industry" (Refiti 2015: 180) leads, in most cases, to nostalgic, vaguely exotic spaces that could be easily exchanged for similar floating signifiers, buildings like the Fale Pasifika seem to demonstrate the generative potential of iconic power. Despite lacking important elements, the fale activates invisible, but still present facets of diasporic culture with its multiple interwoven pasts, unexpected as they may be. In their very displacement, its iconic forms-roof shape, proportions, structural framework, lalava-testify to the permanence and persistence of mana in Pacific diasporic culture (Warburg's observations would support these claims; see endnote 4).

Old concepts with pejorative uses can sometimes be salvaged as serviceable analytical tools. In other cases, it may be necessary to create new terms within the appropriate cultural context. Thus, replacing icon with tupua, for instance, may help staying clear of missionary histories and traditions that could otherwise taint the discussion. Tupua, meaning "a riddle and also to originate" in Samoan, is a state in which a being "begins to open and acquire life", demonstrating life's animation (Refiti, 2010). Relationships might exist between terms like tupua, pule/kupesi (pattern) and heliaki (metaphor) that correspond with those between pattern, icon and metaphor in the English language. Such "correspondences between heterogeneous images", regions and cosmological events (Papapetros, 2010: 42) are likely to be crucial and generative in the diaspora, where "there is no direct connection between ancestral land and the circle of the matai", between the ancestors' mana and the sacred circle.

In its absence, Samoan identity is created and maintained through tofiga (Refiti 2015: 222), which in the homelands locates, gathers and appoints "things and people to places" (7). In the diaspora, tofiga instead "extracts meanings from cultural objects (fale) and concepts (vā, ...)" (222) and bonds them to identity, rather than place. Refiti's example is, indeed, the Fale Pasifika, in which the survival of the (iconic) fale form, in one sense a 'floating signifier', nevertheless represents Pacific identity in New Zealand, underpinned by the "displacement of form, and the persistence of the sense of belonging attached to it" (Refiti, 2015: 5). To understand its iconic power, particularly through concepts generated from within Pacific thought (like tupua, heliaki, or pule/kupesi), allows an appreciation of iconic surface/pattern's participation in the re-invention and articulation of diasporic realities that concepts like traditional, or even classical, obscure. 
REFERENCES

Inscriptions:

Alexander, J. C. (2015). Afterword: The strong program and the iconic turn. Sociologica Sociologica, 9(1).

Alexander, J. C., Bartmański, D., \& Giesen, B. (2012). Iconic power: Materiality and meaning in social life. New York, NY: Palgrave Macmillan.

Arendt, H. (1998). The human condition (2nd ed.). Chicago, IL: University of Chicago Press. (Original work published 1958).

Bartmański, D. (2015). Modes of seeing, or, iconicity as explanatory notion: Cultural research and criticism after the iconic turn in social sciences. Sociologica Sociologica, 9(1), 1-34.

Bartmański, D., \& Alexander, J. C. (2012). Introduction: Materiality and meaning in social life: Toward an iconic turn in cultural sociology. In J. C. Alexander, D. Bartmański, \& B. Giesen (Eds.), Iconic power: Materiality and meaning in social life (pp. 1-12). New York, NY: Palgrave Macmillan.

Brody, E. B. (1987). Rethinking the unconscious: The unacknowledged contribution of Edward Sapir to Claude LéviStrauss and Jacques Lacan. The International Journal of Psychoanalysis, 68, 465-474.

Buck, T. R. H. (1949). Samoan material culture. Honolulu, $\mathrm{HI}$ : Bernice P. Bishop Museum.

Callon, M. (2007). Some elements of a sociology of translation: Domestication of the scallops and the fishermen of St. Brieuc Bay. In K. Asdal, B. Brenna, \& I. Moser (Eds.), Technoscience: The politics of interventions ( $\mathrm{pp}$. 57-78). Oslo: Oslo Academic Press, Unipub.

Clifford, J. (2000). Taking identity politics seriously: 'The contradictory, stony ground ....' In S. Hall, P. Gilroy, L. Grossberg, \& A. McRobbie (Eds.), Without guarantees: In honour of Stuart Hall (pp. 94-112). London, UK: Verso.

Daniel, E. V. (1984). Fluid signs: Being a person the Tamil way. Berkeley, CA: University of California press. de la Durantaye, L. (2009). Giorgio Agamben: A critical introduction. Stanford, CA: Stanford University Press.

Didi-Huberman, G. (2002). The surviving image: Aby Warburg and Tylorian anthropology. Oxford Art Journal, 61-69.

Didi-Huberman, G., Rehberg, V., \& Belay, B. (2003). Artistic survival: Panofsky vs. Warburg and the exorcism of impure time. Common Knowledge, 9(2), 273-285.

Durkheim, É., \& Fields, K. E. (1995), The elementary forms of religious life. New York, NY: Free Press.

Engels-Schwarzpaul, A.-C. (2001). Myth, symbol, ornament: The loss of meaning in transition (Doctor of Philosophy in Education and Art History). The University of Auckland, Auckland. Retrieved from http://researchspace. auckland.ac.nz/handle/2292/48

Engels-Schwarzpaul, A.-C., \& Refiti, A. L. (forthcoming, 2018). Fale Samoa's extended boundaries: Performing place and identity. In E. Grant, K. Greenop, \& A. L. Refiti (Eds.), Handbook of contemporary indigenous architecture. Singapore: Springer.

Fehrenbach, F. (2010). "Du lebst und thust mir nichts": Aby Warburg und die Lebendigkeit der Kunst. In H. Böhme \& J. Endres (Eds.), Der Code der Leidenschaften: Fetischismus in den Künsten (pp. 124-145). München, DE: Fink.

Gell, A. (1996). Vogel's net: Traps as artworks and artworks as traps. Journal of Material Culture, 1(1), 15-38.

Gell, A. (1998). Art and agency: An anthropological theory. Oxford, UK: Clarendon Press.

Gordon, R. B. (1992). Ornament, fantasy, and desire in nineteenthcentury French literature.

Princeton, NJ: Princeton University Press.

Goslinga, G. M. (2006). The ethnography of a South Indian god: Virgin birth, spirit possession, and the prose of the modern world (Unpublished doctoral dissertation). University of California, Santa Cruz, CA.

Hamilton, A. (1901). Maori art. London, UK: The Holland Press.

Harper, D. (2001-2015). Online etymology dictionary. Retrieved from http://etymonline.com/

Hau'ofa, E. (2008). We are the ocean: Selected works. Honolulu, $\mathrm{HI}$ : University of Hawaii Press. Retrieved from http://public.eblib. com/choice/publicfullrecord. aspx?p=3413346

Helu, I. F. (1993). Identity and change in Tongan society since European contact. Journal de la Société des océanistes, 97 , 187-194.

Helu, I. F. \& Janman, P. (2012).

Tongan ark: Culture, power and the infinite. Auckland, NZ: Public Films.

Johnson, C. D. (2012). Memory, metaphor, and Aby Warburg's atlas of images. Ithaca, NY: Cornell University Press.

Keane, W. (2005). Signs are not the garb of meaning: On the social analysis of material things. In D. Miller (Ed.), Materiality (pp. 182-205). Durham, NC: Duke University Press.

Layton, R. (2003). Art and agency: A reassessment. The Journal of the Royal Anthropological Institute, 9(3), 447-464.

MacCannell, D. (1992). Empty meeting grounds: The tourist papers. London, UK: Routledge.

Mallon, S. (2010). Beyond the paperskin. In M. Page, S. Mallon, \& I. Miller (Eds.), 'Paperskin: The art of tapa cloth'. Exhibition catalogue (18 June 2010-26 September 2010) (pp. 23-31). Wellington, NZ: Museum of New Zealand Te Papa Tongarewa.

Marion, J.-L., \& Tracy, D. (2012) God without being: Hors-texte. With a foreword by David Tracy and a new preface by JeanLuc Marion. Chicago, IL: The University of Chicago Press.

Meleisea, M. (1981). Culture is not something you can eat: Some thoughts on cultural preservation and development in Oceania. Museum International (Edition Francaise), 33(2), 122-123.

Papapetros, S. (2003). The eternal seesaw: Oscillations in Warburg's revival. Oxford Art Journal, 26(2), 169-176. 
Papapetros, S. (2010). MICRO/ MACRO: Architecture, cosmology, and the real world. Perspecta, 42, 108-125.

Payne, A. A. (2014). Living stones, crying walls: The dangers of enlivenment in architecture from Renaissance putti to Warburg's "Nachleben". In C. van Eck, J. van Gastel, \& E. van Kessel (Eds.), The secret lives of artworks (pp. 308-339). Leiden, BE: Leiden University Press.

Peirce, C. S., \& Peirce Edition Project (Eds.) (1998). The essential Peirce: Selected philosophical writings (1893-1913) (Vol. 2). Bloomington, IN: Indiana University Press.

Pier, J. (1997, Sept). Versions of the iconic. Ré-inventer le réel / Re-inventing the real. Symposium conducted at the meeting of the HAL. Actes du colloque GRAAT CERCA Retrieved from https:// hal.archives-ouvertes.fr/hal01229512.

Pratt, G. (1893). A grammar and dictionary of the Samoan language with English and Samoan vocabulary. [Place of publication not identified]: Printed by the Religious Tract Society for the London Missionary Society.

Rampley, M. (1997). From symbol to allegory: Aby Warburg's theory of art. The Art Bulletin, 79(1), 41-55.

Rampley, M. (2000). The remembrance of things past: On Aby M. Warburg and Walter Benjamin. Wiesbaden, DE: Harrassowitz.

Rampley, M. (2001a). Iconology of the interval: Aby Warburg's legacy. Word and Image, 17(4), 303-324.

Rampley, M. (2001b). Mimesis and allegory: On Aby Warburg and Walter Benjamin. In R. Woodfield (Ed.), Art history as cultural history: Warburg's projects (pp. 192-234). Retrieved from http://public.eblib.com/ choice/publicfullrecord. aspx? $\mathrm{p}=1666968$.

Refiti, A. L. (2007, 26-27 April 2007). Being-Social. Critiquing Pasifika Education@ the University. Inaugural Conference, New Zealand.

Refiti, A. L. (2009). Whiteness, smoothing and the origin of Samoan architecture. Interstices:
Journal of Architecture and Related Arts (10), 9-19.

Refiti, A. L. (2010). Between monsters and gods. In T. SuaaliiSauni, I. Tuagalu, T. N. Kirifi-Alai, \& N. Fuamatu (Eds.), Su'esu'e manogi-In search of fragrance: Tui Atua Tupua Tamasese Ta'isi and the Samoan Indigenous reference (pp. 370-382). Apia, Samoa: The Centre for Samoan Studies.

Refiti, A. L. (2015). Mavae and tofiga: Spatial exposition of the Samoan cosmogony and architecture (Unpublished doctoral thesis). AUT University, Auckland. Retrieved from https:// aut.researchgateway.ac.nz/ handle/10292/9248.

Ricœur, P. (2006). On translation. Abingdon, UK: Routledge.

Sinjab, L. (2016). A song for Syria. London, UK: BBC World Service.

Taussig, M. (1993). Mimesis and alterity. A particular study of the senses. London, UK: Routledge.

Tengan, T.P. K. (2014). The return of Kū? Re-membering Hawaiian masculinity, warriorhood, and nation. In L. R. Graham \& H. G. Penny (Eds.), Performing indigeneity: Global histories and contemporary experiences (pp. 206-246). Lincoln, NE: U of Nebraska Press.

Tengan, T. P. K., \& Roy, L. M. (2014). 'I search for the channel made fragrant by the maile': Genealogies of discontent and hope. Oceania, 84(3), 315-330

Tomlinson, M., \& Tengan, T. P. K. (2016). Introduction: Mana anew. In M. Tomlinson \& T. P. K. Tengan (Eds.), New mana: Transformations of a classic concept in Pacific languages and cultures (pp. 1-36). Acton ACT,AU: ANU Press.

University of Auckland. (n.d.). Our Place. Retrieved 18 June, 2015, from https://www.auckland. ac.nz/en/about/pacific-at-theuniversity/our-fale.html.

van Eck, C. (2015). Art, agency and living presence: From the animated image to the excessive object. Boston, MA: De Gruyter.

Wendt, A. (1996). Tatauing the post-colonial body. New Zealand electronic poetry centre. Retrieved from http://www.nzepc. auckland.ac.nz/authors/wendt/ tatauing.asp.
Wittgenstein, L. (1958).

Philosophical investigations.

Philosophische untersuchungen (2 ed.). Oxford, UK: Basil Blackwell. 
Endnotes

Thanks to two anonymous reviewers, and to Ty Tengan, Ross Jenner and Carl Douglas, who provided important feedback on the draft. Carl suggested that the iconic could help address "the mirroring role of material productions in producing situated identity", thereby shifting established ideas about 'traditional' places and identities.

${ }^{1}$ Fale Pasifika designates a house dedicated to the people of the Pacific, that is, the indigenous peoples of Polynesia, Micronesia, and Melanesia. Pasifika is a term coined by the New Zealand government to refer to groups of Pacific New Zealanders living in Aotearoa New Zealand. The Pacific, of course, is itself a European construction, and a pan-Pacific identity would cover a huge area, with diverse cultures and perspectives.

${ }^{2}$ At the same time, as one reviewer noted, it is insufficient simply to introduce new terms to avoid heavily discursive Western ones, given that any term-traditional or modernthat is introduced to describe a phenomenon more closely, and with more ontological integrity, still runs the risk of colonised description, since it is itself constituted by the problem.

3 "From a general point of view, the whole of the art work of the Maori [came] under the head of ornament" because it failed as realistic representation (cont...)
(Hamilton, 1901: 6). Just as the denigration of non-Western art as merely ornamental impacts on discussions of ornament in cross-cultural contexts, terms like traditional and authentic are highly problematic yet influential on Western discussions of art, architecture and design (see Engels-Schwarzpaul \& Refiti, forthcoming, 2018).

${ }^{4}$ At the threshold to modernity, European Renaissance identities formed in the interval between historical continuities and discontinuities (Rampley, 2001a: 312). The Renaissance not so much preserved classical cultures as transformed them in a "dialectic of negation and preservation" (307). Classical forms were not simply repeated; rather, collective cultural memory was appropriated and transformed, while inherited images, charged with psychic and symbolic energies, were reactivated from dormancy "in the imagination of a new age" (de la Durantaye, 2009: 71). The Nachleben of traditional forms, which can have an "irresistible power" in moments of cultural crisis (van Eck, 2015: 179), points to both pasts and futures. In the "dual possibility of tradition", (as amnesiac repetition or memorial construction, Rampley, 2001a: 324) (324) ancient motifs, "inherited narratives, symbols, icons and motifs" (Rampley, 2001a: 322) are (re)assembled, transformed and integrated into a new period's cultural sense of self Meaning, in these constellations, relies less on individual figures but on interrelationships and compositions (Johnson, 2012: 28).

${ }^{5}$ This distinction is historically specific; it is, for instance, not present in Gottfried Semper's work but very much in the foreground in Adolf Loos' writings.

${ }^{6}$ As Layton (2003) notes, Gell's rejection of symbolic, conventional aspects of artworks was perhaps unresolved but likely to have been resolved had he not died so soon. Less generously, Fehrenbach (2010) criticises Gell's reliance on binary structures and algebraic models/diagrams. He appears to misread Mitchell and Hooper's discussions of Gell's work, which generally validates most of Gell's theoretical moves. Alexander and Bartmanski support Gell's argument about agency, emphasising a class of agentive social phenomena, not only reflecting but partaking in the social construction of reality; these "visually arresting objectifications" are often striking in form and highly charged in content, with both spheres interwoven and contingently performed, not just conventionally implemented (Bartmanski, 2015: 7).

${ }^{7}$ Since animated images and their agency can dissolve the boundaries between viewer and world (Payne, 2014: 310), patterns can arrest and entrap (Gell, 1998: 82).

${ }^{8}$ Artists took on important tasks of the tufuga, making art "the new ritual attractor, replacing the central posts and the ridge beam [of the fale tele] in this function" (Refiti, 2015: 229). Tufuga faufale would traditionally have been involved in gift-payment sequences marked by important communal events during the completion of sections (like the 'au'au's setting-into-place, marking the connection of earth and sky). In the Fale Pasifika, a horizontal air vent replaced the 'au'au, and published precedents and CAD programmes, rather than a tufuga faufale, controlled the fale's roof shape. Its posts, no longer dedicated to specific ancestors linking house to place, are purely structural, load bearing devices, not lashed but bolted to the beams. The lalava adorning beams and post/beam connections have, for their part, been relieved from structural tasks.

${ }^{9}$ Trans-lation, literally, is a process of displacement and transport from one place to another (Callon, 2007; Harper, 2001-2015).

${ }^{10}$ Anthropologists have recently claimed that iconic signification predominates in the cultures they studied: Goslinga (2006) confirms the "significance of the iconic in producing meaning through relationality" in Tamil culture, endorsing Daniel's argument that iconicity tends to be "the dominant or valued mode of representation" (1984: 231). Likewise, Keane (2005) observed in Indonesia that icons are powerful signs drawing force from their materiality and embeddedness in concrete circumstances. As bundles of forces, icons give rise to and transform "modalities of action and subjectivity" (186).

${ }^{11}$ Ty Tengan considered the term tupua not appropriate for the Hawai'ian context, however, and suggested ki'i instead (pers. comm. 1.7.17, Munich). 